Click www.researchjournal.co.in/online/subdetail.html to purchase.

\title{
A CASE STUDY
}

\section{Knowledge and use of information communication technology (ICT) tools by orange growers}

\author{
V.S. TEKALE, D.N. BHALEKAR, VIDYA V. TAYDE AND S.S. JAMDHADE
}

Received : 04.07.2016; Accepted : 30.09.2016

\begin{abstract}
The present study entitled "Information and communication technology (ICT) tools used by orange growers" was undertaken in Katol taluka in Nagpur district of Vidharbha with sample size of the 100 respondents. The data were collected on personal, socio-economic, communicational and psychological characteristics of respondents, knowledge about of ICT tools, extent of use of ICT tools and problems faced by them studied with the help of pre structured interview schedule. Findings revealed that majority (65\%) of the respondents were belonged to middle age group i.e. between 36 to 50 years, high proportion of respondents (36\%) were educates upto junior college level, large proportion of respondents (40\%) had medium land holding, high proportion of the respondents (31\%) had medium annual income between Rs. 2,00,001 to 3,00,000-/, majority of respondents (62\%) had undertaken orange on an area of (2.01 to 4.00 ha.) majority of respondents (63\%) had medium experience between 10.34 to 24.14 years in orange cultivation, more than two fifth of the respondents $(45 \%)$ had belonged to medium category of social participation, Majority of the respondents $(66 \%)$ were in medium level of extension contact and majority of the respondents (74\%) had medium market orientation. In case of knowledge about ICT tools majority of respondents (69\%) were having medium knowledge about ICT tools. In case of ICT tool wise knowledge, great majority of the respondents had knowledge about ICT tools viz., mobile phones (95\%), followed by television (94\%) and telephone (80\%), respectively. The majority of respondents were also aware about ICT tools video compact disk (60\%), smart phone (60\%), radio (56\%) and bluetooth (56\%), respectively. In case of use of ICT tools majority of respondents (72\%) had medium level of use of ICT tools. In case of ICT tool wise use, great majority of the respondents were regularly using mobile phone (90.00\%), followed by television $(85.00 \%)$ and telephone (70.00\%), respectively. The 40.00 per cent of respondents were regularly using SMS service and smart phone followed by radio $(23.00 \%)$, computer $(20.00 \%)$. Findings of relational analysis revealed that education, social participation, extension contact and market orientation were positive and highly significant with the knowledge. The variables namely land holding and annual income were found to be positive and significant with knowledge of whereas, the independent variable like area under orange was non-significantly correlated with knowledge. Age and experience in orange cultivation was found negative and highly significant with the knowledge of ICT tools. The variables namely education, annual income, social participation, extension contact and market orientation were found to be positive and highly significant relationship with use whereas, the independent variables like land holding and area under were non-significantly correlated with use. Age and experience in orange cultivation were negative and highly correlated with use of ICT tools. The important problems faced by the orange growers in use of ICT tools were, lack of proper knowledge about information technology $(83.00 \%)$, complexity of message and difficulty in interpretation $(80.00 \%)$, inadequate computer facility (78.00\%), lack of understanding standard English language (77.00\%). Whereas, lack of awareness about latest ICTs (71\%), followed by lack of training about using ICT tools (70.00\%), free and paid online services of internet (68.00\%), uneven electricity supply (63\%), lack of proper utility of the messages and poor/ low connectivity of internet, respectively.
\end{abstract}

KEY WORDS : Knowledge, Information communication technology, Orange growers 